\title{
Analisis Kemampuan Pemecahan Masalah Matematika Siswa Berdasarkan Teori APOS (Action, Process, Object, Schema) Ditinjau dari Gaya Kognitif Field Dependent dan Field Independent
}

Author:
Mochamad Jazim ${ }^{1}$
Dinawati Trapsilasiwi $^{2}$
Randi Pratama Murtikusuma ${ }^{3}$
Arifiatun ${ }^{4}$
Affiliation:
${ }_{1,2,3}$ University of Jember, East
Java, Indonesia
${ }^{4}$ SMA Nurul Islam, Jember, East
Java, Indonesia
Corresponding author:
Mochamad Jazim,
mochamadJazim $45 @$ gmail.com
Dates:
Received: 26/2/2021
Accepted: 8/3/2021
Published: 16/3/2021

\section{Author:}

Randi Pratama Murtikusuma ${ }^{3}$

Arifiatun $^{4}$

\section{Affiliation:}

${ }^{1,2,3}$ University of Jember, East

Java, Indonesia

${ }^{4}$ SMA Nurul Islam, Jember, East

Java, Indonesia

\section{Corresponding author:}

Mochamad Jazim,

mochamadJazim45@gmail.com

\section{Dates:}

Accepted: 8/3/2021

Published: $16 / 3 / 2021$

\begin{abstract}
Abstrak. Penelitian ini bertujuan untuk mendeskripsikan dan menganalisis kemampuan pemecahan masalah matematis siswa berdasarkan teori APOS (Action, Peocess, Object, Schema) ditinjau dari Field Dependent dan Field Independent Cognitive Style. Merupakan penelitian deskriptif dengan pendekatan kualitatif. Subjek penelitian ini adalah 34 siswa kelas XI MIPA 1 SMA Nurul Islam Jember, yang dikelompokkan berdasarkan gaya kognitif, 24 siswa yang memiliki gaya kognitif field independent dan 10 siswa yang gaya kognitif field dependent. Metode pengumpulan data menggunakan GEFT (Group Embedded Figure Test), tes kemampuan pemecahan masalah, dan wawancara. Hasil analisis data tes kemampuan pemecahan masalah dan wawancara menunjukkan bahwa pada tahap tindakan siswa dengan gaya kognitif field independent (FI) cenderung mampu menjelaskan makna dan informasi pada soal meskipun tidak menulis. bawah apa yang mereka ketahui. Siswa dengan gaya kognitif field dependent (FD) cenderung mampu menuliskan informasi yang terkandung dalam soal, tetapi mengalami kesulitan dalam menjelaskan makna soal.
\end{abstract}

Kata kunci: Pemecahan masalah matematika, teori APOS, gaya kognitif

Abstract. This study aims to describe and analyze students' mathematical problem-solving abilities based on the APOS (Action, Peocess, Object, Schema) theory in terms of Field Dependent and Field Independent Cognitive Style. This is a descriptive study with a qualitative approach. The subjects of this study were 34 students of class XI MIPA 1 SMA Nurul Islam Jember, who were grouped based on cognitive style, 24 students who had field independent cognitive style and 10 students who had field dependent cognitive style. Data collection methods used the GEFT (Group Embedded Figure Test), problemsolving ability tests, and interviews. The results of the data analysis of the problem-solving ability test and interviews showed that at the action stage students with the independent field cognitive style (FI) tended to be able to explain the meaning and information on the questions even though they did not write. below what they know. Students with the field dependent cognitive style (FD) tend to be able to write down the information contained in the questions, but have difficulty explaining the meaning of the questions

Keywords: mathematics problem solving, APOS theory, cognitive style

\section{JoMEaL}

Copyright:

This work is licensed under a Creative Commons Attribution-ShareAlike 4.0 International License.

Read online:

https://jurnal.unej.ac.id/index.php/JOMEAL/index or scan barcode beside.

How to cite this article:

Jazim, M., Trapsilasiwi, D., Murtikusuma, R., \& Arifiatun, A. (2021). Analisis Kemampuan Pemecahan Masalah Matematika Siswa Berdasarkan Teori APOS (Action, Process, Object, Schema) Ditinjau dari Gaya Kognitif Field Dependent dan Field Independent. Journal of Mathematics Education and Learning, 1(1), 51-62. Retrieved from https://jurnal.unej.ac.id/index.php/JOMEAL/article/view/24375 


\section{Pendahuluan}

Matematika merupakan suatu ilmu yang mempunyai peranan yang sangat penting dalam kehidupan manusia, karena matematika berpengaruh pada perkembangan semua bidang seperti bidang ekonomi, teknologi, sosial, dan sebagainya Hal ini menunjukkan bahwa belajar matematika sangat diperlukan, karena setiap kegiatan yang kita jalani dalam kehidupan sehari-hari sangat erat kaitannya dengan matematika. Keberhasilan mempelajarinya akan membuka pintu karir yang cemerlang.

Matematika merupakan disiplin ilmu yang mempunyai sifat khusus jika dibandingkan dengan disiplin ilmu yang lain. Oleh karena itu pembelajaran matematika perlu untuk memperhatikan kemampuan peserta didik yang memiliki kemampuan yang berbeda-beda, sehingga pembelajaran matematika dapat diterimapeserta didik sesuai dengan tujuan yang diharapkan (Chairani, 2016). Suatu pembelajaran matematika dikatakan berhasil jika tujuan pembelajaran matematika tercapai. Berdasarkan Peraturan Menteri Pendidikan Nasional RI Nomor 22 Tahun 2006, dijelaskan bahwa salah satu tujuan pembelajaran matematika di sekolah adalah agarpeserta didik memiliki kemampuan memecahkan masalah yang meliputi kemampuan memahami masalah, merancang model matematika, menyelesaikan model dan menafsirkan solusi yang diperoleh (depdiknas, 2006). Berdasarkan tujuan pembelajaran matematika tersebut, maka diperlukan suatu kompetensi yang harus dimiliki siswa yaitu kemampuan pemecahan masalah matematika. Kemampuan pemecahan masalah matematika selalu melibatkan aktivitas berpikir yang akan berkembang dalam pembelajaran matematika

Pengertian sederhana dari pemecahan masalah adalah proses penerimaan masalah sebagai tantangan untuk menyelesaikannya. Cooney mengungkapkan bahwa kemampuan pemecahan masalah memungkinkan siswa menjadi lebih analitis dalam mengambil keputusan di dalam kehidupan dan menjadi tolak ukur dalam memahami suatu konsep matematika, sehingga perlu dilakukan analasis kemampuan pemecahan masalah siswa untuk mengetahui tingkat pemahaman yang dimiliki oleh siswa terhadap konsep-konsep matematika (susanto, 2015). Pemahaman terhadap suatu konsep matematika merupakan hasil konstruksi atau rekonstruksi terhadap objek-objek matematika yang dilakukan melalui aktivitas berupa aksi, proses, dan objek-objek yang diorganisasikan dalam suatu skema untuk memecahkan masalah matematika. Aktivitas tersebut dibingkai dalam Teori APOS (Action, Process, Object, and Schema). Teori APOS dapat digunakan sebagai suatu alat analisis untukmedeskripsikan bagaimana pengetahuan matematika terbentuk dalam diri seseorang dan dapat digunakan untuk melihat apakah suatu pemahaman siswa terhadap konsep matematika telah sampai pada tahap tertentu atau belum (Dubinsky, 2001).

Dalam memecahkan suatu permasalahan matematika setiap siswa memiliki cara penyelesaian yang berbeda-beda. Hal ini karena setiap individu memiliki karakteristik khas yang tidak dimiliki oleh individu lain dalam hal menanggapi suatu informasi (Suanto, 2015). Argarini mengungkapkan bahwa gaya kognitif merupakan karakteristik individu dalam berpikir, merasakan, mengingat, memecahkan masalah dan membuat keputusan. Gaya kognitif memiliki pengaruh dalam kehidupan seseorang, misalnya menentukan bidang akademiknya, menentukan cara belajar, bagaimana seseorang tersebut berinteraksi dengan orang lain, dan lain sebagainya (Argarini, Budiyono, \& Sujadi, 2014).

Gaya kognitif dapat dibedakan atas beberapa pengelompokan, menurut Usodo (2011) pengelompokannya berdasarkan perbedaan psikologis siswa dalam menghadapi situasi lingkungannya. Berdasarkan pengelompokan ini gaya kognitif dibedakan atas gaya kognitif Field 
Dependent (FD) dan gaya kognitif Field Independent (FI) dengan menggunakan tes GEFT (Usodo, 2011).

Tabel 1. Hubungan Karakteristik Teori APOS terhadap Indikator Pemecahan Masalah Berdasarkan Teori APOS

\begin{tabular}{|c|c|c|}
\hline $\begin{array}{c}\text { Tahap Teori } \\
\text { APOS }\end{array}$ & Karakteristik & Indikator Pemecahan Masalah \\
\hline Aksi & $\begin{array}{ll}\text { a. } & \text { Memerlukan langkah- langkah } \\
\text { rinci untuk melakukan } \\
\text { transformasi. } \\
\text { b. Kinerja berupa kegiatan } \\
\text { prosedural. }\end{array}$ & $\begin{array}{l}\text { IA1. Siswa dapat menuliskan unsur- } \\
\text { unsur yang diketahui pada soal. } \\
\text { IA2. Siswa dapat mengetahui informasi } \\
\text { yang ada pada soal. }\end{array}$ \\
\hline Proses & $\begin{array}{l}\text { Untuk melakukan transformasi tidak } \\
\text { perludiarahkan dari rangsangan } \\
\text { eksternal. }\end{array}$ & $\begin{array}{l}\text { IP. Siswa dapat mengubah yang } \\
\text { diketahui dalam soal menjadi model } \\
\text { matematika. }\end{array}$ \\
\hline Objek & $\begin{array}{ll}\text { a. } & \text { Dapat melakukan aksi-aksi } \\
\text { pada objek. } \\
\text { b. Objek merupakan suatu } \\
\text { pemahaman konseptual. }\end{array}$ & $\begin{array}{l}\text { IO1. Siswa mampu menyelesaikan soal } \\
\text { dan langkah yang digunakan } \\
\text { beserta alasan sesuai dengan } \\
\text { metode penyelesaian (eliminasi, } \\
\text { substitusi, gabungan) } \\
\text { IO2. Siswa dapat menentukan solusi } \\
\text { dari permasalahan pada soal }\end{array}$ \\
\hline Skema & $\begin{array}{l}\text { a. Dapat menghubungkan aksi, } \\
\text { proses, objek, suatukonsep } \\
\text { dengan konsep lainnya. } \\
\text { b. Memahami berbagai aturan } \\
\text { atau rumus yangperlu } \\
\text { dilibatkan atau } \\
\text { digunakan. }\end{array}$ & $\begin{array}{l}\text { IS1. Siswa dapat menarik kesimpulan } \\
\text { dengan menghubungkan aksi proses } \\
\text { dan objekSiswa dapat menjelaskan } \\
\text { proses penyelesaian yang telah } \\
\text { tuliskan mulai awal sampai akhir } \\
\text { menemukan jawaban }\end{array}$ \\
\hline
\end{tabular}

Berdasarkan uraian di atas, maka dilakukan penelitian dengan tujuan untuk mengetahui kemampuan pemecahan masalah matematika siswa khususnya materi persamaan linear tiga variabel berdasarkan teori APOS pada masing-masing siswadengan gaya kognitif yang berbeda. Oleh karena itu, didapatkan judul penelitian berupa "Analisis Kemampuan Pemecahan Masalah Matematika Siswa Berdasarkan Teori APOS (Action, Process, Object, Schema) Ditinjau dari Gaya Kognitif Field Dependent dan Field Independent.

\section{Metode Penelitian}

Jenis penelitian ini merupakan penelitian deskriptif dengan pendekatan kualitatif. Subjek penelitian adalah empat siswa kelas XI MIPA 1 SMA Nurul Islam Jember. Tahapan dalam penelitian ini yaitu membuat instrumen penelitian, menentukan daerah penelitian, mengajukan surat ijin penelitian, dan berkoordinasi dengan guru tempat penelitian untuk menentukan jadwal penelitian. Instrumen penelitian yang dibuat pada penelitian ini yaitu tes kemampuan pemecahan masalah yang berupa dua soal uraian materi Sistem Persamaan Linear Tiga Variabel, dan pedoman wawancara untuk meninjau kembali jawaban siswa. Instrumen yang telah dibuat, perlu dilakukan validasi untuk menentukan kevalidan dari instrumen tersebut. Validasi dilakukan oleh dua dosen pendidikan 
matematika Universitas Jember. Hasil validasi menunjukkan bahwa tes kemampuan pemecahan masalah dinyatakan valid dengan skor 2,8 dari skala 3, sedangkan pedoman wawancara dinyatakan valid dengan skor 2,9 dari skala 3. Tahap selanjutnya adalah pengumpulan data dengan memberikan tes GEFT kepada seluruh siswa XI MIPA 1 SMA Nurul Islam Jember untuk menggolongkan siswa sesuai dengan gaya kognitifnya. Selanjutnya dipilih 4 subjek dengan nilai tertinggi pada tiap gaya kognitif, yaitu 2 siswa dengan gaya kognitif filed independent (FI) dan 2 siswa dengan gaya kognitif field dependent (FD). Subjek yangtelah terpilih untuk mewakili masing-masing gaya kognitif diberikan soal tes kemampuan pemecahan masalah untuk mengetahui kemampuan pemecahan masalah siswa berdasarkan teori APOS dan dilakukan wawancara untuk memperoleh informasi yang lebih dalam dari hasil pekerjaan siswa dalam menyelesaikan tes kemampuan pemecahan masalah.

\section{Hasil dan Pembahasan}

Berdasarkan hasil analisis data tes GEFT, dari 34 siswa diperoleh data sebanyak 10 siswa memiliki gaya kognitif field dependent dan 24 siswa memiliki gaya kognitif field independent. Subjek penelitian dipilih 2 siswa dengan skor paling tinggi pada masing-masing tipe gaya kognitif berdasarkan hasil tes GEFT. Selanjutnya keempat subjek penelitian tersebut diberikan tes pemecahan masalah dan wawancara.

Kemampuan pemecahan masalah matematika siswa berdasarkan teori APOS pada ditinjau dari gaya kognitif field dependent dan field independent dideskripsikan dengan memperhatikan kesesuaian dan kecenderungan siswa sebagai sampel penelitian yang mewakili kedua tipe gaya kognitif dan dilihat dari indikator pemecahan masalah berdasarkan teori APOS, yaitu aksi, proses, objek dan skema. Berdasarkan analisis hasil tes kemampuan pemecahan masalah dan hasil wawancara siswa field independent dan field dependent, maka dapat ditarik kesimpulan tentang kemampuan pemecahan masalah siswa field independent dan field dependent.

Data hasil Tes kemampuan pemecahan masalah dan wawancara siswa berdasarkan teori APOS pada tahap Aksi, disajikan seperti pada Tabel 2.

Tabel 2. Deskripsi Hasil Tes Kemampuan Pemecahan Masalah dan Hasil WawancaraSiswa pada Tahap

\begin{tabular}{|c|c|c|}
\hline & & Aksi \\
\hline Gaya Kognitif & Siswa & Deskripsi \\
\hline \multirow{2}{*}{$\begin{array}{c}\text { Field } \\
\text { Independent }\end{array}$} & $\mathrm{FI}_{1}$ & $\begin{array}{l}\text { - Mampu menjelaskan kembali maksud dari soaldengan bahasa } \\
\text { sendiri } \\
\text { - Tidak menuliskan yang diketahui dan ditanyakanpada soal } \\
\text { - Menyebutkan informasi yang terdapat pada soaldengan } \\
\text { lengkap }\end{array}$ \\
\hline & $\mathrm{FI}_{2}$ & $\begin{array}{l}\text { - Mampu menjelaskan kembali maksud dari soaldengan bahasa } \\
\text { sendiri } \\
\text { - Tidak menuliskan yang diketahui dan ditanyakanpada soal } \\
\text { - Menyebutkan informasi yang terdapat pada soaldengan } \\
\text { lengkap }\end{array}$ \\
\hline
\end{tabular}




\begin{tabular}{|c|c|c|}
\hline Gaya Kognitif & Siswa & Deskripsi \\
\hline \multirow{2}{*}{ Field Dependent } & $\mathrm{FD}_{1}$ & $\begin{array}{l}\text { - Kesulitan menjelaskan kembali maksud dari soaldengan bahasa } \\
\text { sendiri } \\
\text { - Menuliskan yang diketahui dan ditanyakan pada soal } \\
\text { - Menyebutkan informasi yang terdapat pada soaldengan } \\
\text { lengkap }\end{array}$ \\
\hline & $\mathrm{FD}_{2}$ & $\begin{array}{l}\text { - Kesulitan menjelaskan kembali maksud dari soaldengan bahasa } \\
\text { sendiri } \\
\text { - Menuliskan yang diketahui dan ditanyakan pada soal } \\
\text { - Dapat menyebutkan informasi yang terdapat padasoal dengan } \\
\text { lengkap }\end{array}$ \\
\hline
\end{tabular}

Siswa field independent dan field dependent cenderung melalui tahap Aksi pada proses pemecahan masalah matematika berdasarkan teori APOS, kemampuanpemecahan masalah siswa field independent dan siswa field dependent yang ditunjukkan oleh $\mathrm{FI}_{1}, \mathrm{FI}_{2}, \mathrm{FD}_{1}$ dan $\mathrm{FD}_{2}$, seluruhnya telah memenuhi tahap aksi dalam pemecahan masalah matematika dengan baik dan benar. Hal tersebut dilihatdari kemampuan siswa field independent dan siswa field dependent dalam memahami informasi yang terdapat pada permasalahan 1 dan 2, meskipun siswa field independent tidak menuliskan informasi yang ada pada permasalahan 1 dan 2.Namun, masih mampu menyebutkan informasi dan unsur-unsur yang diketahui secara lisan pada permasalahan 1 dan 2, hal tersebut dilakukan agar menghemat waktu untuk mengerjakan permasalahan. Berikut kutipan wawancara bersamasiswa FI pada tahap aksi.

$\begin{array}{ll}\mathrm{P}_{1} 008 & \text { : Coba jelaskan permasalaan dengan bahasa sendiri } \\ \mathrm{FI}_{1} 008 & \text { : Disini ada } 3 \text { orang bernama Delby, Jepri, dan Yusuf. Kita diminta untuk } \\ & \text { menghitung berapa umur dari ketiga orang tersebut lalu disuruh } \\ & \text { menyebutkan pada tahun berapa mereka lahir } \\ \mathrm{P}_{1} 009 & \text { : Baik, lalu apa yang diketahui dan ditanyakan pada soal tersebut? } \\ \mathrm{FI}_{1} 009 \quad \text { : Yang diketahui yaitu jumlah usia ketiga orang tersebut pada } 3 \text { tahun yang } \\ \\ \text { lalu, usia Delby } 2 \text { tahun kurangnya dari usia jepri, } 2 \text { kali usia yusuf adalah } \\ \text { 6 tahun lebihnya dari usia Delby ditambah usia Jepri, dan sekarang adalah } \\ \text { tahun 2020. Untuk yang ditanyakan yaitu tahun mereka lahir pak }\end{array}$

Siswa field dependent mampu menuliskan dan menyebutkan informasi yang ada pada permasalahan 1 dan 2. Namun, siswa FD2 mengalami kesulitan dalam memahami maksud soal sehingga siswa seperti hanya membaca soal yang ada dan tidak mampu menjelaskan dengan bahasa sendiri. Hal tersebut dikarenakansiswa tersebut tidak bisa memilah informasi-infromasi penting yang terdapat pada soal. Berikut hasil pekejaan siswa FD pada tahap aksi.

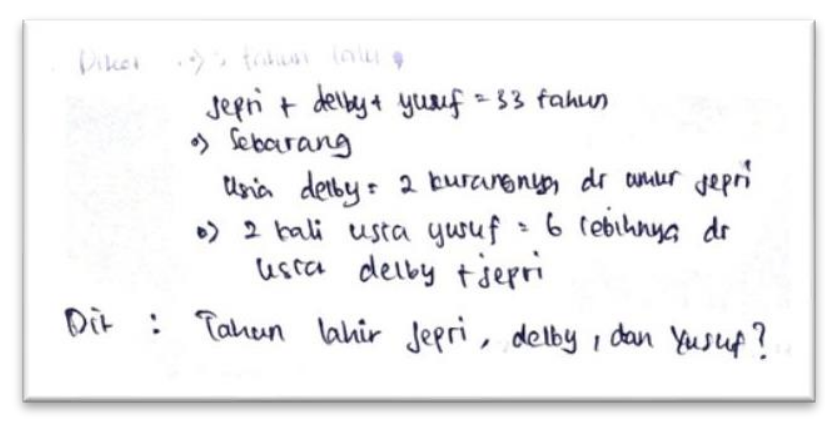


Gambar 1. Hasil pekejaan siswa FD pada tahap aksi

Data hasil Tes kemampuan pemecahan masalah dan wawancara siswa berdasarkan teori APOS pada tahap Proses, disajikan seperti pada Tabel 3.

Tabel 3. Deskripsi Hasil Tes Kemampuan Pemecahan Masalah dan Hasil WawancaraSiswa pada Tahap Proses

\begin{tabular}{|c|c|c|}
\hline Gaya Kognitif & Siswa & Deskripsi \\
\hline \multirow{2}{*}{$\begin{array}{c}\text { Field } \\
\text { Independent }\end{array}$} & FI1 & $\begin{array}{l}\text { - Mampu memodelkan dengan benar masalah yang ada di } \\
\text { dalam soal kedalam bentuk atau model matematika } \\
\text { - Mampu menjelaskan tahapan dalam memodelkan }\end{array}$ \\
\hline & $\mathrm{FI} 2$ & $\begin{array}{l}\text { - Mampu memodelkan dengan benar masalah yang ada di } \\
\text { dalam soal kedalam bentuk atau model matematika } \\
\text { - Mampu menjelaskan tahapan dalam memodelkan }\end{array}$ \\
\hline \multirow[t]{2}{*}{ Field Dependent } & FD1 & $\begin{array}{l}\text { - Salah dalam memodelkan masalah yang ada di dalam } \\
\text { soal kedalam bentuk atau model matematika } \\
\text { - Mampu menjelaskan tahapan dalam memodelkan }\end{array}$ \\
\hline & FD2 & $\begin{array}{l}\text { - Salah dalam memodelkan masalah yang ada di dalam } \\
\text { soal kedalam bentuk atau model matematika } \\
\text { - Mampu menjelaskan tahapan dalam memodelkan }\end{array}$ \\
\hline
\end{tabular}

Siswa field independent dan field dependent cenderung melalui tahap Proses pada proses pemecahan masalah matematika berdasarkan teori APOS. Kemampuanpemecahan masalah siswa field independent yang ditunjukkan oleh $\mathrm{FI}_{1}$ dan $\mathrm{FI}_{2}$, seluruhnya telah memenuhi tahap proses dalam pemecahan masalah matematika dengan baik dan benar. Hal tersebut dilihat dari kemampuan siswa field independent dalam mengubah yang diketahui pada permasalahan 1 dan 2 menjadisuatu model matematika dengan baik dan benar. Berikut hasil pekejaan siswa FI pada tahap proses.

$$
\begin{aligned}
& (D-3)+(3-3)+(Y-3)=33 \\
& D=J-2 \\
& 2 Y=D+J+6
\end{aligned}
$$

Gambar 2. Hasil pekejaan siswa FI pada tahap proses

Siswa field dependent yang ditunjukkan oleh $\mathrm{FD}_{1}$ dan $\mathrm{FD}_{2}$, seluruhnya telah memenuhi tahap proses dalam pemecahan masalah matematika, namun masih terdapat beberapa kesalahan yang dilakukan dalam memodelkan permasalahan ke bentuk matematika. Hal tersebut dikarenakan siswa field dependent tidak terbiasa mengerjakan soal seperti permasalahan 1 dan 2. Berikut hasil pekejaan siswa FD pada tahap proses. 


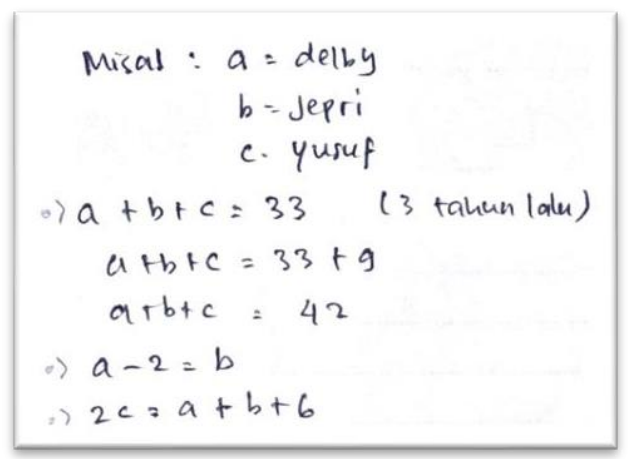

Gambar 3. Hasil pekejaan siswa FD pada tahap proses

Data hasil Tes kemampuan pemecahan masalah dan wawancara siswa berdasarkan teori APOS pada tahap Objek, disajikan seperti pada Tabel 4.

Tabel 4. Deskripsi Hasil Tes Kemampuan Pemecahan Masalah dan Hasil WawancaraSiswa pada Tahap

\begin{tabular}{|c|c|c|}
\hline Gaya Kognitif & Siswa & Deskripsi \\
\hline \multirow{2}{*}{$\begin{array}{c}\text { Field } \\
\text { Independent }\end{array}$} & FI1 & $\begin{array}{l}\text { - Tidak menuliskan langkah-langkah secara terperinci } \\
\text { - Mampu menjelaskan langkah-langkah penyelesaian } \\
\text { dengan jelas dan benar } \\
\text { - Mampu menentukan himpunan penyelesaian dengan } \\
\text { benar }\end{array}$ \\
\hline & $\mathrm{FI} 2$ & $\begin{array}{l}\text { - Kurang teliti dalam pengerjaan sehingga himpunan } \\
\text { penyelesaian salah, tetapi dilakukan pembenaran } \\
\text { - Mampu menjelaskan langkah-langkah penyelesaian } \\
\text { dengan jelas dan benar } \\
\text { - Mampu menentukan himpunan penyelesaian dengan } \\
\text { benar }\end{array}$ \\
\hline \multirow[t]{2}{*}{$\begin{array}{c}\text { Field } \\
\text { Dependent }\end{array}$} & FD1 & $\begin{array}{l}\text { - Tidak mampu menjelaskan kembali hasil pekerjaannya } \\
\text { pada tahap objek dengan baik dan benar } \\
\text { - Kurang memahami konsep } \\
\text { - Salah dalam menentukan himpunan penyelesaian }\end{array}$ \\
\hline & FD2 & $\begin{array}{l}\text { - Kesulitan dalam menjelaskan kembali hasil pekerjaannya } \\
\text { pada tahap objek dengan baik dan benar } \\
\text { - Kurang memahami konsep } \\
\text { - Salah dalam menentukan himpunan penyelesaian }\end{array}$ \\
\hline
\end{tabular}

Siswa field independent dan field dependent cenderung melalui tahap Objekpada proses pemecahan masalah matematika berdasarkan teori APOS. Kemampuanpemecahan masalah siswa field independent yang ditunjukkan oleh $\mathrm{FI}_{1}$ dan $\mathrm{FI}_{2}$, seluruhnya telah memenuhi tahap objek dalam pemecahan masalah matematika dengan baik dan benar. Hal tersebut dilihat dari kemampuan siswa FI1 dalam menyelesaikan permasalahan 1 dan 2 dengan menggunakan metode dan langkah- langkah yang sesuai hingga didapatkan solusi yang diharapkan pada masing-masingpermasalahan, sedangkan siswa FI2 mampu menyelesaikan permasalahan 2 denganmenggunakan metode dan langkah-langkah yang sesuai hingga didapatkan solusi yang diharapkan. Pada permasalahan 1 siswa FI2 mampu menggunakan metode dan langkah-langkah yang sesuai, namun solusi yang didapatkan kurang tepat, hal ini dikarenakan siswa FI2 kurang teliti dalam proses pengerjaan, yaitu dalam melakukan 
perhitungan, akan tetapi siswa menyadari kesalahan yang dilakukannyapada saat meninjau kembali hasil pekerjaan yang diperoleh pada saat wawancara. Berikut hasil pekejaan siswa FI pada tahap objek.

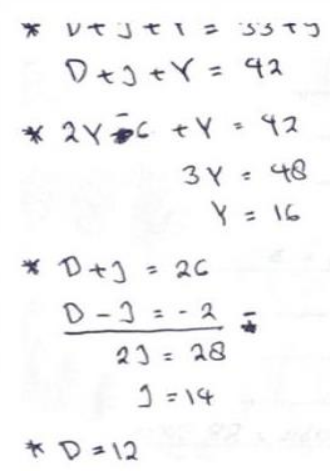

Gambar 4. Hasil pekejaan siswa FI pada tahap objek

Siswa field dependent ditunjukkan oleh FD1 dan FD2, seluruhnya telah memenuhi tahap objek dalam pemecahan masalah matematika. Hal tersebut dilihat dari kemampuan siswa FD1 dan FD2 dalam menyelesaikan permasalahan 1 dan 2 dengan menggunakan metode dan langkah-langkah yang sesuai, namun solusi yang didapatkan dari keduanya masih kurang tepat, hal itu dikarenakan siswa FD1 dan FD2 salah dalam memodelkan permasalahan matematika pada tahap sebelumnya. Selain itu, FD1 juga kesulitan dalam menjelaskan kembali proses pemecahan masalah yang dilakukan, dikarenakan kurangnya pemahaman konsep yang dimiliki FD1, sedangkan FD2 mampu dalam menjelaskan kembali proses pemecahan masalah yang dilakukan, namun masih mengalami kesalahan pada proses menghitung, hal ini dikarenakan siswa FD2 kurang teliti dalam proses pengerjaan.

Berikut hasil pekejaan siswa FI pada tahap proses. Berikut hasil pekejaan siswa FDpada tahap objek.

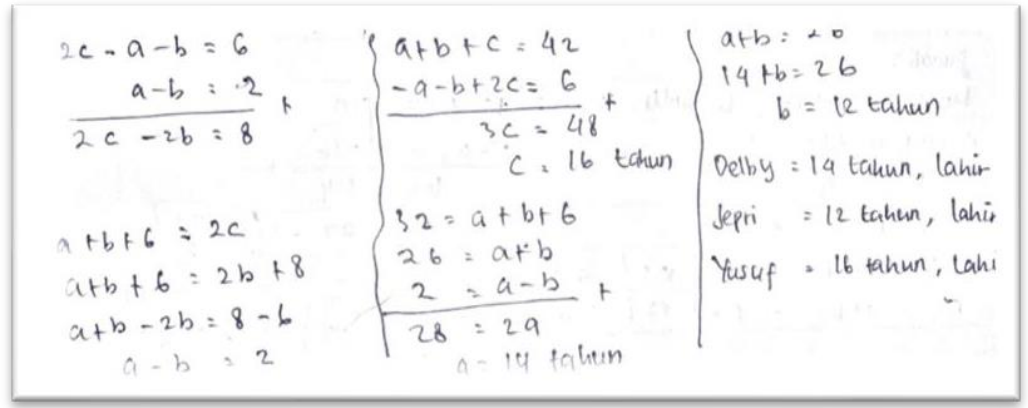

Gambar 5. Hasil pekejaan siswa FD pada tahap objek

Data hasil Tes kemampuan pemecahan masalah dan wawancara siswaberdasarkan teori APOS pada tahap Skema, disajikan seperti pada Tabel 5. 
Tabel 5. Deskripsi Hasil Tes Kemampuan Pemecahan Masalah dan Hasil WawancaraSiswa pada Tahap

\begin{tabular}{|c|c|c|}
\hline \multicolumn{3}{|r|}{ Skema } \\
\hline Gaya Kognitif & Siswa & Deskripsi \\
\hline \multirow{2}{*}{$\begin{array}{c}\text { Field } \\
\text { Independent }\end{array}$} & $\mathrm{FI}_{1}$ & $\begin{array}{l}\text { - Tidak menuliskan secara lengkap dalam menyelesaikan } \\
\text { masalah } \\
\text { - Mampu menjelaskan dalam memanfaatkan informasi yang } \\
\text { terdapat pada tahap objek untuktahap selanjutnya } \\
\text { - Mampu menentukan jawaban akhir dengan benar } \\
\text { - Mampu menjelaskan proses pengerjaan dari awal sampai } \\
\text { akhir menemukan jawaban }\end{array}$ \\
\hline & $\mathrm{FI}_{2}$ & $\begin{array}{l}\text { - Mampu menjelaskan dalam memanfaatkan informasi yang } \\
\text { terdapat pada tahap objek untuktahap selanjutnya } \\
\text { - Mampu menentukan jawaban akhir dengan benar setelah } \\
\text { melakukan sedikit pembenaran } \\
\text { - Mampu menjelaskan proses pengerjaan dari awal sampai } \\
\text { akhir menemukan jawaban }\end{array}$ \\
\hline \multirow[b]{2}{*}{ Field Dependent } & $\mathrm{FD}_{1}$ & $\begin{array}{l}\text { - Mampu menjelaskan dalam memanfaatkan informasi yang } \\
\text { terdapat pada tahap objek untuktahap selanjutnya } \\
\text { - Salah dalam menentukan jawaban akhir } \\
\text { - Mampu menjelaskan proses pengerjaan dari awal sampai } \\
\text { akhir menemukan jawaban }\end{array}$ \\
\hline & $\mathrm{FD}_{2}$ & $\begin{array}{l}\text { - Mampu menjelaskan dalam memanfaatkan informasi yang } \\
\text { terdapat pada tahap objek untuktahap selanjutnya } \\
\text { - Salah dalam menentukan jawaban akhir } \\
\text { - Mampu menjelaskan proses pengerjaan dari awal sampai } \\
\text { akhir menemukan jawaban }\end{array}$ \\
\hline
\end{tabular}

Siswa field independent dan field dependent cenderung melalui tahap Skema pada proses pemecahan masalah matematika berdasarkan teori APOS, kemampuan pemecahan masalah siswa field independent dan siswa field dependent yang ditunjukkan oleh FI1, FI2, FD1 dan FD2, seluruhnya telah memenuhi tahap skema dalam pemecahan masalah matematika dengan baik dan benar. Hal tersebut dilihat dari kemampuan siswa field independent dalam memanfaatkan informasi yang ada pada soal atau tahap sebelumnya untuk menyelesaikan tahap berikutnya hingga dapat ditarik suatu kesimpulan yang baik dan benar. Sedangkan Siswa field dependent mampu memanfaatkan informasi yang ada pada soal atau tahap sebelumnya untuk menyelesaikan tahap berikutnya hingga dapat ditarik suatu kesimpulan, namun masih terdapat kesalahan yang dilakukan siswa field dependent baik dari tahap proses hingga penarikan kesimpulan sebagai solusi dari permasalahan matematika. Berikut hasil pekejaan siswa FI dan FD pada tahap skema.

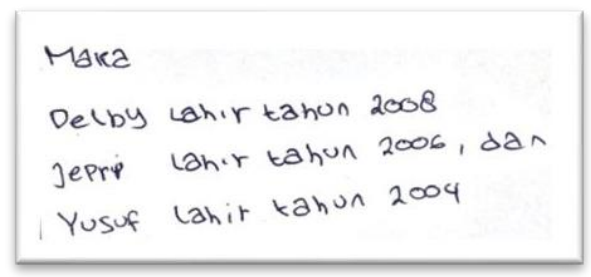


Gambar 6. Hasil pekejaan siswa FI pada tahap skema

$$
\begin{aligned}
& \text { Delby }=14 \text { tahun, lahir tahun } 2006 \\
& \text { Jepri }=12 \text { tahun, lahir tahun } 2008 \\
& \text { Yusuf }=16 \text { tahun, lahir tahun } 2004
\end{aligned}
$$

Gambar 7. Hasil pekejaan siswa FD pada tahap skema

Dalam penelitian ini terlihat bahwa siswa bergaya kognitif field independentsudah mampu memahami dan menerapkan konsep yang terdapat pada materiSistem Persamaan Linear Tiga Variabel. Dapat dilihat dalam menyelesaikan masalah, siswa bergaya kognitif field independent mampu memahami maksud dantujuan dari soal. Siswa bergaya kognitif field independent menyelesaikan soal tersebut dengan strategi atau pengalaman mereka sendiri. Dalam menyelesaikan soal, siswa FI menyelesaikan dengan bebas atau tidak terpaku dengan langkahlangkah yang tersusun secara lengkap dan rinci. Hal ini didukung dengan hasil penelitian yang dilakukan oleh Purnomo (2017) yang mengungkapkan bahwa siswafield independent lebih kreatif dalam memecahkah masalah matematika daripada siswa field dependent (Purnomo \& Sugiarti, 2017). Sedangkan siswa bergaya kognitif field dependentkurang memahami dan menerapkan konsep yang terdapat pada materi Sistem Persamaan Linear Tiga Variabel. Dapat dilihat dalam menyelesaikan masalah, siswa bergaya kognitif field dependent salah dalam memodelkan matematika dan siswa kesulitan dalam menjelaskan proses penyelesaian yang dilakukannya. Dalammenyelesaikan soal, siswa FD menyelesaikan dengan langkah-langkah yang tersusun secara lengkap dan rinci. Hal ini sejalan dengan pendapat Nasution (2006)yang mengungkapkan bahwa seseorang dengan gaya kognitif field dependent dalammemecahkan masalah memerlukan petunjuk yang lebih banyak atau terperinci daripengetahuan yang didapat sebelumnya dan memerlukan langkah demi langkah dalam pengerjaannya (Nasution, 2006).

Berdasarkan deskripsi yang telah dijabarkan diatas, siswa bergaya kognitif fiel independent lebih baik dalam memecahkan masalah daripada siswa bergaya kognitif field dependent. Hal ini didukung oleh hasil penelitian Alimuddin (2019) yang menyatakan bahwa dalam menyelesaikan tugas atau memecahkan suatu masalah (problem solving) yang menghendaki suatu keterampilan maka individu field independent akan menghasilkan lebih baik dibandingkan dengan individu fielddependent [9]. Selain itu, hasil dari penelitian yang dilakukan oleh Prabawa (2017) yang menunjukkan bahwa siswa dengan gaya kognitif field independent (FI)cenderung memiliki kemampuan pemecahan masalah yang lebih baik daripada siswa dengan gaya kongnitif field dependent (FD) (Prabawa, Usodo, \& Pambudi, 2019). Begitupun dengan hasil penelitian yang dilakukan oleh Prabowo et al. (2019), hasil yang diperoleh menunjukkan bahwa siswa field independent mendapat skor yang lebih tinggi daripada siswa field dependent. Siswa field independent mampu menyelesaikan masalah di setiap tingkatan game dalam waktu singkat dan mendapatkan sedikit kesalahan dari pada siswa field dependent (Prabawa, Usodo, \& Pambudi, 2019).

Hasil penelitian ini menunjukkan bahwa siswa dengan gaya kognitif field independent maupun field dependent cenderung mampu melalui seluruh tahapan teori APOS dalam proses 
pemecahan masalah, Hal ini bertentangan dengan hasil penelitian yang dilakukan oleh Afgani et al. (2017) bahwa tidak ada mahasiswa yang mencapai tahap proses, objek atau skema dengan sempurna (Afgani, Suryadi, \& Dahlan, 2017). Siswa FI cenderung mengerjakan soal dengan bebas, sedangkan siswa FD cenderung mengerjakan soal secara terperinci atau terpaku terhadap langkah-langkah yang tersusun secara lengkap akan tetapi masih mengalami kesalahan dalam proses pemecahan masalah, khususnya pada tahap proses dan objek. Hal ini sesuai dengan penelitian (Latifah, 2018) yang menyatakan bahwa, dalam menyelesaikan suatu permasalahan matematika setiap siswa memiliki cara penyelesaian yang berbeda (Latifa \& Susanto, 2018). Hal ini juga didukung dengan pernyataan yang diungkapkan oleh (Nasution, 2006), bahwa siswa FI tidak memerlukan petunjuk yang terperinci, sedangkan FD memerlukan petunjuk yang lebih banyak untuk memahami sesuatu, bahkan hendaknya tersusun langkah demi langkah dalam memecahakan permasalahan matematika (Nasution, 2006).

\section{Kesimpulan}

Berdasarkan hasil analisis data dan pembahasan pada bab sebelumnya, dapat ditarik kesimpulan tentang kemampuan pemecahan masalah matematika siswa dalam menyelesaiakan soal Sistem Persamaan Linear Tiga Variabel berdasarkan Teori APOS (Action, Process, Object, Schema) ditinjau dari gaya kognitif field dependent dan field independent. Kesimpulan yang diperoleh yaitu, siswa dengan gaya kognitif field independent dalam memecahkan permasalahan matematika cenderung bebas atau tidak terpaku dengan langkah-langkah yang tersusun secara lengkap dan rinci, serta mampu melalui seluruh tahapan pada teori APOS, yang meliputi tahap aksi, proses, objek, dan skema dengan baik dan benar.Siswa dengan gaya kognitif field dependent dalam memecahkan masalah matematika cenderung terikat atau terpaku dengan langkah-langkah yang tersusunsecara lengkap dan rinci serta mampu melalui seluruh tahapan pada teori APOS, yang meliputi tahap aksi, proses, objek, dan skema, namun masih terdapat kesalahan-kesalahan yang dilakukan pada tahap proses dan tahap objek.

Berdasarkan hasil penelitian yang didapat, ada beberapa saran yang diberikan yaitu, (1) Hasil penelitian menunjukkan bahwa adanya persamaan dan perbedaan kemampaun siswa bergaya kognitif field dependent dan field independent dalam memecahkan masalah, sehingga hasil penelitian tersebut dapat digunakan sebagai bahan masukan untuk menyusun pembelajaran yang cocok digunakan untuk kedua gaya kognitif tersebut. (2) Disarankan kepada siswa untuk lebih mendalami konsep suatu materi dan tidak hanya menyelesaikan masalah berdasarkan contoh saja, dan sebaiknya lebih sering latihan mengerjakan soal-soaluraian untuk meningkatkan kemampuan pemecahan masalah; (2) bagi peneliti lain,sebaiknya materi yang digunakan untuk penelitian merupakan materi yang ditempuh oleh subjek atau siswa, bukan materi semester sebelumnya. Hal ini agar data yang diperoleh lebih akurat karena siswa masih ingat dengan materi yang diujikan.

\section{Daftar Pustaka}

Afgani, M. W., Suryadi, D., \& Dahlan, J. A. (2017). Analysis of Undergraduate Students' Mathematical Understanding Ability of the Limit of Function Based on APOS Theory Perspective. Journal of Physics: Conference Series, 895(1). https://doi.org/10.1088/1742$\underline{6596 / 895 / 1 / 012056 .}$ 
Alimuddin, R. (2019). Charactheristics Of Solution Of Open EndedProblems Reviewed From Student Cognitive Style. Global Science Education Journal, 1(1), 65-72.

Argarini, D., Budiyono, \& Sujadi, I. (2014). Karakteristik berpikir kreatifsiswa kelas VII SMP N 1 Kragan dalam memecahkan dan mengajukan masalah matematika materi perbandingan ditinjau dari gaya kognitif. Mathematics and Mathematics Education, 4(2), 1-12.

Chairani, Z. (2016). Metakognisi Siswa dalam Pemecahan MasalahMatematika. Deepublish.

Depdiknas. (2006). "Permendiknas Nomor 22 Tahun 2006 Tentang Standar Isi Mata Pelajaran Matematika".

Dubinsky, E. (2001). Using a Theory of Learning in College Mathematics Courses. MSOR Connections, 1(2), 10-15.

Latifah, I. W dan Susanto. (2018) "Profil Berpikir Siswa Peserta Olimpiade Matematika dalam Menyelesaikan Masalah Aljabar," kadikma, vol.9, hal. 145.

Nasution. (2006). Berbagai Pendekatan dalam Proses Belajar danMengajar. PT Bumi Aksara.

Prabawa, E. A. (2017). Analisis Kemampuan Pemecahan Masalah DitinjauDari Gaya Kognitif Siswa pada Model Project Based Learning Bernuansa Etnomatematika. Journal of Mathematics Education Research, 6(1), 120- 129.

Prabowo, A., Usodo, B., \& Pambudi, I. (2019). Field-independence versusfield-dependence: A serious game on trigonometry learning. Journal of Physics: Conference Series, 1188(1). https://doi.org/10.1088/1742- 6596/1188/1/012100

Purnomo, R. C., \& Sugiarti, T. (2017). Profil Kreativitas dalam PemecahanMasalah Matematika Ditinjau dari Gaya Kognitif Field Independent (FI) dan Field Dependent (FD). Jurnal Edukasi, 4(2), 9-14.

Susanto, H. A. (2015). Pemecahan Masalah Berdasar Gaya Kognitif. Deepublish. https://doi.org/10.11120/msor.2001.01020010

Usodo, B. (2011). Profil Intuisi Mahasiswa Dalam Memecahkan MasalahMatematika Ditinjau Dari Gaya Kognitif Field Dependent dan Field Independent. Prosiding Seminar Nasional Matematika Dan Pendidikan Matematika UNS 2011, 95-172. 